most deprived fifth, although the 2001 standardised mortality ratio was not significantly higher for men than for women in the highest fifth.

\section{Comment}

The number of suicides increased for young adults in a 20 year period when the number among older adults declined. The rise in standardised mortality ratios was larger for young men $(72.43 \%)$ than young women $(19.04 \%)$. The suicide gap between the most and least deprived areas widened more for young women; there were over six times as many deaths in the most compared with the least deprived fifth in 1999-2001 (152 $v 24)$. For young men the rates rose in every fifth, with a particularly large and significant rise in the most deprived fifth.

Recent media and political attention has focused on rising suicide rates among young men. The relative rise in suicides among young people in poor areas in Scotland, however, has increased during the 1990s and warrants more attention. While suicide polarisation is greater for young women, partly because of declines in the numbers in less deprived areas, the suicide rate in the most deprived fifth is particularly high for young men.

The Scottish Executive aims to reduce the number of suicides by $20 \%$ between 2003 and $2013 .{ }^{4}$ One "priority risk group" is defined geographically as "people in isolated or rural communities." Those in the most deprived areas are not prioritised, although the executive acknowledges that efforts are needed to help vulnerable people in society and address inequalities. Various factors that influence suicide, such as drug

\section{What is already known on this topic}

Suicide is more common in Scotland than in the rest of the United Kingdom, and rates have been rising, particularly among young men

What this study adds

There is a growing social polarisation of suicide among young people in the most deprived parts of Scotland.

misuse, divorce, and unemployment are more common in deprived areas. ${ }^{5}$ Our results suggest that these areas should be targeted among the "priority risk groups" in the future.

Contributors: All authors participated in design, execution, analysis, and writing up of different parts of the study. PB had the main coordinating responsibility for the study design and $\mathrm{DE}$ for the analysis. $\mathrm{PB}$ is guarantor.

Funding: DE was funded by an overseas research studentship award. This research was undertaken as part of his $\mathrm{PhD}$ dissertation.

Competing interests: None declared.

Ethical approval: Not required.

1 McLoone P. Suicide and deprivation in Scotland. BMJ 1996;312:543-4. McLoone P, Boddy FA. Deprivation and mortality in Scotland, 1981 and 1991. BMJ 1994;309:1465-74.

3 Exeter D, Boyle PJ, Feng Z, Flowerdew R, Schierloh N. The creation of 'consistent areas through time' (CATTs) in Scotland, 1981-2001. Population Trends (in press).

4 Scottish Executive. Choose life: a national strategy and action plan to prevent suicide in Scotland. Edinburgh: Stationery Office, 2002.

5 Gunnell D, Frankel S. Prevention of suicide: aspirations and evidence. GMI 1994;308:1227-33.

(Accepted 9 November 2004)

doi 10.1136/bmj.38328.559572.55
See also pp 167, 175

Estonian-Swedish Institute of

Suicidology,

Hariduse 6, Tallinn

10119, Estonia

Airi Värnik

director, professor of

psychiatry

Kairi Kõlves

researcher

Swedish National and Stockholm

County Centre for

Suicide Research

and Prevention of

Mental Ill-Health

(NASP), Karolinska

Institute, Stockholm

Danuta Wasserman

professor of psychiatry

and suicidology

Correspondence to:

A Värnik

Airi.Varnik@ipm.ki.se

BMJ 2005;330:176-7

\title{
Suicide among Russians in Estonia: database study before and after independence
}

Airi Värnik, Kairi Kõlves, Danuta Wasserman

Migration has been reported as an important risk factor for suicide. Immigrants have a higher risk than exists in their countries of origin and than among the native population of their new country. ${ }^{12}$ According to the 1934 population census, before the second world war native Estonians constituted $88.1 \%$ of the total population of Estonia. By 1989, however, because of geopolitical changes related to the incorporation of Estonia into the Soviet Union, the Russian minority had grown to about $30 \%$. We examined how the radically changed sociopolitical status of the Russian minority after the dissolution of the Soviet Union was reflected in their suicide rates.

\section{Methods and results}

We compared suicide rates of Russians in Estonia, Estonians in Estonia, and inhabitants of Russia from before (1983-90) and after the dissolution of the Soviet Union during Estonian independence (1991-8). We collected data from the World Health Organization reports on age adjusted suicide rates for the Russian Federation. We derived data on the population in Estonia by nationality from the Estonian Statistical Office. The nationality of those who committed suicide was specified on the death certificates.

According to the 1989 census, Estonian-Russians include Russians (78.7\%), Ukrainians (8.1\%), Belorussians $(4.7 \%)$, and others $(8.5 \%)$. We termed inhabitants of Russia "Russians" in the study. In the Russian Federation $82.6 \%$ of inhabitants were native Russians.

Means of age adjusted suicide rates were high for the three nationalities during 1983-90 (table). The rates of suicide were lower among Russians in Estonia than Estonians $(\mathrm{P}=0.061)$. During the transition period (1991-8), suicide rates increased for all three nationalities (by 39.2\% for Russians in Estonia, 25.9\% for Russians in Russia, and 17.1\% for Estonians) (table). Thus, the Estonian Russians had a significantly higher

This article was posted on bmj.com on 15 December 2004: http://bmj.com/cgi/doi/10.1136/bmj.38328.454294.55 
suicide rate than Estonians $(\mathrm{P}=0.005)$ and Russians in Russia $(\mathrm{P}=0.032)$. Of the total numbers of suicides during both periods studied, $80 \%$ were in men.

\section{Comment}

During the Soviet era Russians had the lowest suicide rate in Estonia, which might have been due to their privileged status. Russian immigrants in Estonia had privileges in salaries and housing, and their needs received greater attention than local populations in Estonia and in Russia. There was no need for integration and acculturation, and Russians maintained their sense of ethnic identity and confidence in belonging to a privileged class.

After Estonian independence in 1991, Estonian Russians had to adapt themselves to new conditions, study Estonian as an official language, and apply for citizenship. The loss of privileged position and ideals, many years after immigration, may have caused stress leading to suicidal behaviours ${ }^{2}$ and suicide rates significantly higher than for Estonians in Estonia and Russians in Russia.

During 1995-8, stabilisation and adaptation processes began in Estonian society. Convergence of the Russian and Estonian suicide rates in Estonia in 1998 could be interpreted as an adaptation to sociopolitical

\section{What is already known on this topic}

Migration is an important risk factor for suicide, and immigrants have a higher risk of suicide than exists in their country of origin and in the native population of the new country

\section{What this study adds}

During the Soviet period the suicide rate among the Russian minority in Estonia was lower than the rate in native Estonians

When Russians changed from a privileged to a non-privileged minority in independent Estonia, the suicide rate in the Russian minority in Estonia became significantly higher than in native Estonians and in Russians in Russia
Mean age adjusted suicide rates per 100000 and paired samples $t$ tests by nationality in two time periods for Estonia and Russia

\begin{tabular}{lcc} 
& \multicolumn{1}{c}{$\mathbf{1 9 8 3 - 9 0}$} & $\mathbf{1 9 9 1 - 8}$ \\
\hline Estonians in Estonia & $29.2^{\star}(26.4$ to 32.0$)$ & $34.2^{*} \quad(30.4$ to 38.0$)$ \\
\hline Russians in Estonia & $27.8^{\star}(24.4$ to 31.1$)$ & $38.7^{\star} \quad(34.0$ to 43.3$)$ \\
\hline Russians in Russia & $29.0^{\star}(24.3$ to 33.7$)$ & $36.5^{\star} \quad(32.1$ to 40.8$)$ \\
\hline Paired samples test: & & \\
\hline Estonians in Estonia/Russians in Estonia & $1.44 \dagger(-0.09$ to 2.98$)$ & $-4.48 \dagger \quad(-7.14$ to -1.82$)$ \\
& $t=2.22, \mathrm{P}=0.061$ & $t=-3.99, \mathrm{P}=0.005$ \\
\hline Russians in Russia/Russians in Estonia & $1.22 \dagger(-0.49$ to 2.94$)$ & $-2.22 \dagger \quad(-4.18$ to -0.25$)$ \\
& $t=1.69, \mathrm{P}=0.135$ & $t=2.67, \mathrm{P}=0.032$ \\
\hline
\end{tabular}

*Mean suicide rate.

†Mean difference.

changes and efforts of the Estonian government to integrate the Russian minority. ${ }^{3}$

The statistics on suicides in the former Soviet Union are valid and reliable. ${ }^{45}$ Then the procedure for reporting and registration was uniform and remained the same in the Russian Federation and also in Estonia. The present study is limited, however, because of the relatively small number of suicides in Estonia.

We thank Max Goldstein, Swedish National and Stockholm County Centre for Suicide Research and Prevention of Mental Ill-Health (NASP), Karolinska Institute, Stockholm, and Liina-Mai Tooding for advice on statistics.

Contributors: AV and DW designed the study and wrote the paper. KK and AV participated in data collection. KK did the statistical analysis. All authors interpreted the data. AV is guarantor.

Funding: AV received grants from the Swedish Research Council and the Estonian Scientific Foundation Project No 5349. He also holds the Olof Palme professorship at NASP, Karolinska Institute.

Competing interests: None declared.

Ethical approval: Not required.

Burwill PW. Migrant suicide rates in Australia and in country of birth. Psychol Med 1998;28:201-8.

2 Hovey JD. Acculturative stress, depression, and suicidal ideation among Central American immigrants. Suicide Life Threat Behav 2000;30:125-39.

Värnik A, Kõlves K. Estonians' and non-Estomians' suicides. Tallinn-Tartu, Estonia: Tallinna Lennuliikluse Trükikoda, 2001:14.

4 Värnik A, Wasserman D, Palo E, Tooding LM. Registration of external causes of death in the Baltic States 1970-1997. Eur J Public Health 2001:11:84-8.

5 Wasserman D, Värnik A, Dankowicz M, Eklund G. Suicide preventive effects of perestroika in the former USSR: the role of alcohol restriction. Acta Psychiatr Scand 1998;98(suppl 394):1-41.

(Accepted 14 September 2004)

doi $10.1136 /$ bmj.38328.454294.55

\section{Submitting articles to the $B M J$}

We are now inviting all authors who want to submit a paper to the $B M J$ to do so via the web (http://submit.bmj.com)

Benchpress is a website where authors deposit their manuscripts and editors go to read them and record their decisions. Reviewers' details are also held on the system, and when asked to review a paper reviewers will be invited to access the site to see the relevant paper. The system is secure, protected by passwords, so that authors see only their own papers and reviewers see only those they are meant to. The system is run by Highwire Press, who host bmj.com, and is already being used by 30 journals, including most of the BMJ Publishing Group's specialist journals.

For authors in particular the system offers several benefits. The system provides all our guidance and forms and allows authors to suggest reviewers for their paper-something we'd like to encourage. Authors get an immediate acknowledgement that their submission has been received, and they can watch the progress of their manuscript. The record of their submission, including editors' and reviewers' reports, remains on the system for future reference.

Anyone with an internet connection and a web browser can use the system.

The system itself offers extensive help, and the BMJ Online Submission Team is geared up to help authors and reviewers if they get stuck. We see Benchpress as part of our endeavour to improve our service to authors and reviewers and, as always, we'd welcome feedback.

Benchpress is accessed via http://submit.bmj.com or via a link from bmj.com 